University of Miami Law School University of Miami School of Law Institutional Repository

1974

\title{
The Preparations for the Law of the Sea Conference
}

John R. Stevenson

Bernard Oxman

Follow this and additional works at: https://repository.law.miami.edu/fac_articles Part of the Law of the Sea Commons 


\title{
The Preparations for the Law of the Sea Conference *
}

\author{
By John R. Stevenson * and Bernard H. Oxman **
}

I.

\section{INTRODUCTION}

The United Nations General Assembly has convened a new Conference on the Law of the Sea. Its object is to achieve comprehensive agreement on the international law of the sea. Most if not all members of the United Nations, as well as other states, can be expected to attend the substantive session in Caracas this summer.

The Conference will have before it the results of the work of the 91member UN Seabed Committee which has been carrying on preparations for the Conference since 1970. The Committee's reports include draft texts, usually in the form of alternatives, notably with respect to the question of the legal regime for the deep seabeds and the prevention of ocean pollution; proposals made by a large number of states on one or more issues; and a comprehensive list of subjects and issues. ${ }^{1}$ To these should be added a number of studies prepared by the UN Secretariat at the Committee's request.

The Conference must likewise take into account the four Conventions ${ }^{2}$ adopted by the 1958 Conference on the Law of the Sea on the basis of texts prepared by the International Law Commission; relevant decisions of the International Court of Justice; the Declaration of Principles regarding the deep seabeds adopted by the UN General Assembly in 1970; ${ }^{3}$ and a vast array of official statements and scholarly writings regarding the nature and content of the existing law of the sea.

- The views expressed herein are those of the authors and do not necessarily represent the views of the Department of State or the U.S. Government.

- Of the Board of Editors. Special Representative of the President for the Law of the Sea Conference.

- Assistant Legal Adviser for Ocean Affairs, U.S. Department of State.

1 Reports of the Committee on the Peaceful Uses of the Seabed and the Ocean Floor Beyond the Limits of National Jurisdiction, 25 UN GAOR SuPP. 21, UN Doc. A/8021 (1970); 26 UN GAOR SUPP. 21, UN Doc. A/8421 (1971); 27 UN GAOR SUPP. 21, UN Doc. A/8721 (1972); 28 UN GAOR SuPr. 21, UN Doc. A/9021 (1973). Hereinafter abbreviated as 25, 26, 27, 28, REP. The 1973 Report is in six volumes; since the texts of proposals submitted to Subcommittees I and III are not printed therein, they are cited hereinafter by individual UN Doc. number.

2 Convention on the High Seas, 13 UST 2312; TIAS 5200, 450 UNTS 82; 52 AJIL 842 (1958). Convention on the Continental Shelf, 15 UST 471; TIAS 5578; 499 UNTS 311; 52 AJIL 858 (1958). Convention on the Territorial Sea and the Contiguous Zone, 15 UST 1606; TIAS 5639; 516 UNTS 205; 52 AJIL 834 (1958). Convention on Fishing and Conservation of the Living Resources of the High Seas, 17 UST 138; TIAS 5969; 559 UNTS 285; 52 AJIL 851 (1958).

8 GA Res. 2749, 25 UN GAOR, SUPp. 28, at 24, UN Doc. A/8028 (1970). 
From a strictly legal perspective, the absence of definitive texts on important issues in itself renders the magnitude of the task impressive. A hypothetical group of 150 completely disinterested experts would encounter considerable difficulty in achieving timely and sensible results. Once it is recognized that important political, security, environmental, economic, and scientific interests are significantly affected by the rules of the law of the sea, that these interests are divergent not only as between countries but within individual countries as well, and that governments are frequently inclined to avoid difficult decisions as long as possible, it is quite easy to conclude that the odds against a new law of the sea treaty are overwhelming. There are, however, positive incentives for a timely and successful conference which significantly affect the situation, and lead most if not all countries to believe that a timely and successful Law of the Sea Conference is in their interest.

The most important reason why states are pressing forward with the Conference is widespread dissatisfaction with the existing legal regime or lack of it in the oceans. Some believe that respect for certain aspects of the traditional law of the sea is breaking down, and that interests protected by that traditional law are being jeopardized. This has been the reaction, for example, to unilateral extensions of the territorial sea and other forms of coastal state jurisdiction. Some believe that the traditional law does not adequately protect current or anticipated interests. This has been the reaction by many states to the conservation and economic problems created by the development of large and highly mobile distantwater fishing fleets. Some believe that the absence of sufficiently, preciso legal rules to deal with new or newly perceived problems and uses, such as pollution of the marine environment and the development of technology to exploit the deep seabeds, could prejudice their interests.

A great deal of political and legal argumentation is heard in defense of each of these perspectives. On the one hand, it is asserted that centuries of legal development cannot be disregarded. On the other hand, it is said that a large number of countries were unable to participate fully in that development and should not be compelled to live with the results. In fact, however, few if any delegations believe that all of existing law should either be retained or discarded at the Conference.

Dissatisfaction with the existing situation does not, of course, mean that the only solution is a new comprehensive multilateral treaty on the law of the sea. However, a number of factors have combined to persuade most governments that it is the best available solution.

The number of states involved in resolving a particular problem may be large and may in fact present an unbalanced "regional" negotiating situation. A coastal state interested in protecting its fishing interests off its coast can only be assured of such protection if all actual or potential users are bound by the measures taken. At a Law of the Sea Conference, it can seek communities of interest with other coastal states and work out a solution acceptable to both coastal and distant-water fishing states. 
At a meeting of the states immediately concerned, it may be hopelessly outnumbered by foreign states fishing off its coast.

In many situations, the problem is itself of global or nearly global magnitude. For example, passage through an important international strait affects the coastal state or states, a large number of states with vessels using the strait, and an even larger number of states with security or economic interests in the use of the strait by foreign vessels or aircraft.

The interrelationship of issues further complicates attempts at isolated solutions. For example, the United States and other nations are prepared to agree to a universal extension of the territorial sea to 12 miles provided there is adequate agreement on free transit of straits used for international navigation. Concomitantly, many coastal nations have stated that a commitment to limit their territorial sea to 12 miles would not be desirable without special provision to protect their interests in living and non-living resources beyond that limit. The respective positions of states on the boundaries of coastal state resource jurisdiction are in turn affected by the nature of the resource regime within those limits.

A further incentive for agreement derives from the international community's general interest in the success of these negotiations. While it would not be accurate or helpful to regard the Law of the Sea Conference, or any other UN effort, as a "test" of the efficacy of global multilateral diplonacy, the political implications of failure to produce a timely treaty would not be limited to the oceans. On the other hand, a timely and successful conference could instill new confidence in the United Nations and would surely contribute to the strengthening of international law and institutions generally.

Although many of the most important issues involved do not relate to the relative economic development of states, some do; and, more importantly, some attempts have been made to polarize the negotiations along developed-developing country lines. A number of delegations are acutely aware of the danger this presents for a conference whose success will be judged not by the mere adoption of a treaty but by the conclusion of a treaty generally acceptable to both developed and developing countries. There have been favorable indications in the recent preparatory meetings that enough, if not all, national and regional leaders will have a sufficiently broad conception of this general problem, and of its relationship to broader interests, to make every effort to ensure the success of the Conference.

For ease of reference, the issues involved in the law of the sea negotiations can be analyzed in accordance with the Seabed Committee's allocation of topics to its three Subcommittees of the whole. The first Subcommittee was concerned with an international regime and an international organization (in UN parlance, international machinery) for the seabed beyond the limits of national jurisdiction; it established one working group to deal with these issues. Subcommittee II had the broadest and most complex mandate of all; it was concerned with most of the traditional 
law of the sea issues, including the territorial sea, straits, the high seas, and fisheries, as well as the seabed within national jurisdiction; it established one working group of the whole. Subcommittee III was concerned with pollution and scientific research; it established one working group on pollution and one on scientific research and transfer of technology.

\section{II.}

\section{The Seabed beyond National Jurisdiction-Subcommtttee I}

Draft articles bearing on the work of Subcommittee $I$, and narrative working papers, were introduced by the United States, ${ }^{4}$ the United Kingdom, ${ }^{5}$ France, ${ }^{8}$ Tanzania, ${ }^{7}$ the Soviet Union, ${ }^{8}$ Poland, ${ }^{\circ}$ certain Latin American states, ${ }^{10}$ certain landlocked and shelf-locked countries, ${ }^{11}$ Canada, ${ }^{12}$ and Italy. ${ }^{13}$ The comprehensive approach of Malta $^{14}$ to an ocean space treaty also bears on this as well as virtually all other aspects of the negotiation. In addition, proposals relating to archeological and historical treasures found on the seabed were introduced by Turkey ${ }^{15}$ and Greece. ${ }^{10}$

In the working group of Subcommittee I, the first such group to be established, the focus has been on the preparation of a comprehensive and consolidated set of texts illustrating areas of agreement and disagree-

4 USA: Draft United Nations convention on the international sen-bed area; 25 Rex. 130-76 (1970).

5 United Kingdom: Working paper on international régime, 25 Rep. 177-84 (1970); United Kingdom: International sea-bed régime-proposals for elements of a convention, 26 Rep. 83-91 (1971).

${ }^{\circ}$ France: Proposals for establishment of a régime for the exploration and the exploitation of the seabed, 25 REP. 185-90 (1970).

7 Tanzania: Draft Statute for an international sea-bed authority, 26 REP. 51-64 (1971).

8 USSR: Provisional draft article on use of the sea-bed for peaceful purposes, 26 REP. 67-75 (1971); USSR: Preamble to a treaty on the use of the sea-bed for peaceful purposes, 28 REP. II, 166 (1973).

- Poland: Working paper concerning an international organization on exploration and exploitation, 26 REP. 76-81 (1971).

${ }^{10}$ Chile, Colombia, Ecuador, El Salvador, Guatemala, Guyana, Jamaica, Mexico, Panama, Peru, Trinidad and Tobago, Uruguay, Venezuela: Working paper on the régime for the sea-bed and ocean floor, and the subsoil thereof beyond the limits of national jurisdiction, 26 REP. 93-101 (1971).

${ }^{11}$ Afghanistan, Austria, Belgium, Hungary, Nepal, Netherlands, Singapore: Preliminary working paper, 26 REP. 194-96 (1971).

12 Canada: International sea-bed régime and machinery working paper, 26 Rep. 205-25 (1971).

13 Italy: Articles on composition of the council, UN Doc. A/AC.138/SC.1/L.24 (July 24, 1973); Italy: Preliminary draft articles concerning basic principles of the régime and regulations for the granting and administration of licenses for the exploration and exploitation of minerals, UN Doc. A/AC.138/SC.I/L.28 (August 14, 1973).

14 Malta: Draft ocean space treaty, 26 ReP. 105-93 (1971).

15 Turkey: Articles on archaeological and historical treasures, UN Doc. A/AC.138/ SC.I/L.21 (March 28, 1973).

${ }^{10}$ Greece: Draft article on protection of archaeological and historical treasures, UN Doc. A/AC.138/SC.I/L.25 (August 14, 1973). 
ment on the status, scope, and basic provisions of the international regime, and the status and scope, functions, and powers of the international machinery. ${ }^{17}$ This document was prepared initially by the chairman of the working group, principally on the basis of proposals made by states, and was elaborated within the working group. In the form transmitted by the Subcommittee to the Committee and included in the Committee's report to the UN General Assembly, it contains 52 articles and certain additional texts. Disagreements are indicated therein either by the use of square brackets or by alternative texts under each article.

It has been generally understood in the Committee's work that the landward limits of the international seabed area will coincide with the seaward limit of coastal state jurisdiction over the seabed resources, thus in effect placing all seabed resource activities under the regulatory authority either of coastal states or of the international regime and machinery. While the issue of the location of this boundary has a very significant bearing on the importance and nature of the international regime and machinery for the area beyond national jurisdiction, this issue has been discussed principally in Subcommittee II, and it will be addressed in connection with the preparatory work of that Subcommittee.

The large number of articles drafted on the subject of the seabed beyond national jurisdiction is attributable to the inherent technical complexities of establishing both an international regime and an international organization to deal with the exploration and exploitation of the resources of a vast, but until recent years largely unknown and unused, area of this planet. In many important respects, the effort is unprecedented, although some important parallels can be drawn to the work of existing international organizations, such as the International Civil Aviation Organization.

The most critical problems involved concern three interrelated issues: These are the nature of the resource exploration and exploitation system, the functions and powers of the international organization, referred to in the working group texts as the Authority, and the nature of the decisionmaking process. In large measure, the alternative texts included on a variety of articles reflect the different positions of states on these issues.

The alternative approaches to the resource exploration and exploitation system are set out in Article 9, under the title "Who May Exploit the Area." They are as follows: ${ }^{18}$

\section{[Alternative A]}

All exploration and exploitation activities in the Area shall be conducted by a Contracting Party or group of Contracting Parties or natural or juridical persons under its or their authority or sponsorship, subject to regulation by the Authority and in accordance with the rules regarding exploration and exploitation set out in these Articles.

17 Working Group I, Texts illustrating areas of agreement and disagreement: Report of Subcommittee I, Annex III, 28 ReP. II, 39 (1973); see also Working Group I: Texts illustrating areas of agreement and disagreement; 27 REP. 81-108 (1972).

1828 Rer. II, 57-58 (1973). 


\section{[Alternative B]}

All activities of scientific research and exploration of the Area and exploitation of its resources and other related activities shall be conducted by the Authority directly or, if the Authority so determines, through service contracts or in association with persons natural or juridical.

\section{[Alternative C]}

All exploration and exploitation activities in the Area shall be conducted by the Authority either directly or in such other manner as it may from time to time determine. If it considers it appropriate and subject to such terms and conditions as it may determine the Authority may decide to grant licenses for such activities to a Contracting Party or group of Contracting Parties or through them to natural or juridical persons under its or their authority or sponsorship, including multinational corporations or associations.

Licenses may also be issued for this purpose to international organizations active in the field at the discretion of the Authority.

\section{[Alternative D]}

All exploration and exploitation activities in the Area shall be conducted by a Contracting Party or group of Contracting Parties or natural or juridical persons under its or their authority or sponsorship, subject to regulation by the Authority and in accordance with the rules regarding exploration and exploitation set out in these Articles. The Authority may decide, within the limits of its financial and technological resources, to conduct such activities.

A note to Article 9 indicates that consideration should be given to whether or not to set out ". . . as is done in some proposals, the general rules regarding resource activities in the Area."

These could include, inter alia, according to the type of administration adopted as regards exploration and exploitation, rules on: notice to mariners and other safety procedures, areas to be allotted, work requirements, work plans, inspection, service contracts, licensing, joint ventures, fees payable, revocation of service contracts, revocation of licenses and integrity of investments ...

It has been increasingly accepted in the preparatory work that both public and private entities would in fact engage in exploration and exploitation and that direct exploitation with the Authority's own personnel, capital, and equipment is not feasible. Accordingly, the issue has become essentially one of employing a nondiscretionary licensing system, or a system of negotiated service contracts and joint ventures with discretion in the Authority to choose between investors, or a combination of the two systems. Articles 38 and 44 contemplate that a special organ of the Authority would perform these functions. The "Operations Commission" is the organ frequently associated with licensing, while the "Enterprise" is the term for the organ usually associated with the contractual exploitation system. The United States has strongly insisted on nondiscretionary access on satisfaction of agreed conditions prescribed in advance, preferably in the treaty itself. 
Although broad philosophical differences underlie these approaches, certain key issues are reflected in all of them. Will the Authority deal only: with states, or with private investors directly, or both? Will the system ensure reasonable and secure investment conditions and permit adequate planning and predictability for a sufficient period of time? Will potential consumers be assured of supply at reasonable cost? How can the desires of developing countries to share the benefits and have an opportunity for participation be accommodated?

The United States has been strongly of the view that general rules dealing with these matters should be included in the treaty, rather than left to the Authority's discretion. This issue has for the moment been left open (as indicated in the note to Article 9 referred to above).

There appears to be broad agreement that the Authority would exercise certain functions and powers in respect of resource exploration and exploitation as such, although this agreement is conditional in the case of many countries, including the United States, on the nature of the Authority's decisionmaking processes.

In some cases, there are differences over whether a particular function should be performed by the Authority at all. One difference is occasioned by the fears of certain land producers of hard minerals and petroleum that seabed production may adversely affect the prices of these minerals. Two related questions are involved:

First will there be an adverse impact on prices in the light of growing world demand for these products? As for petroleum, the limits of coastal state economic jurisdiction being discussed render the likelihood of large scale, economically viable production in the international area highly remote. While hard minerals are expected to be produced principally from manganese nodules from the deep seabed within the international area, there is considerable doubt as to the likelihood of adverse impact, except in the case of cobalt, where the effect will be largely limited to only one state where cobalt is produced as a copper byproduct. It should also be noted that nickel will be the primary metal of economic interest for a considerable time. The world's major producers of nickel are not developing countries.

Second, what, if anything, should the Authority do about such price declines if they occur? Some states would propose some means of assistance to the affected land producers by the Authority, while others propose price or production controls. The latter proposal, which has been strongly opposed by the United States, could undercut rights of access and the stability of investment conditions, as well as the interests of consumers, and would be discriminatory if applied solely to production in the international area.

The problem of the decisionmaking process is in essence one of adequately protecting the interests of all concerned. Decisions by a majority or two-thirds voting majority in an Assembly (the plenary organ of the Authority), as proposed by a number of developing countries, cannot assure such a result from the perspectives of those states and their nationals most likely to be involved in deep seabed activities. 
A state normally becomes bound by new international rules by agreeing to them. It is widely recognized, on the one hand, that only a limited number of the necessary rules and regulations may be included in the treaty itself and, on the other hand, that a requirement of express universal agreement on additional rules and regulations for seabed exploitation would probably prove unworkable. Thus, the problem is one of providing states with sufficient assurances in the treaty so that they will consent in advance to be bound by certain rules adopted through the prescribed procedures. The establishment of precise treaty criteria governing the scope of rules, subject to dispute settlement procedures, is one approach that has been suggested. The establishment of an expert nonpolitical commission that drafts rules after consultation with all member states is another.

The requirement of approval by a Council of limited size, with adequately balanced representation and voting procedures, is for some an indispensable element. Article 35 indicates a substantial difference of view on this critical matter. For others, approval by a substantial proportion of all member states is equally indispensable. In this connection, some have proposed that the Assembly vote on rules submitted by the Council, while others have proposed that the Council submit rules directly to the Contracting Parties for review and that the rules would not go into effect if one-third or more object within a specified period. The United States has argued for the latter system, noting that it would not be practicable for the Assembly to meet often or in continuous session, and that states may wish to consult a variety of experts and agencies in their respective capitals before reaching a final decision and accordingly would probably not wish their representatives to have to make rapid decisions in a plenary organ. Similar procedures are, of course, used by other international organizations, such as the International Civil Aviation Organization.

Finally, the timely availability of impartial dispute settlement machinery, applicable both to disputes between states and operators and disputes with organs of the Authority, is considered essential by a number of states, including the United States.

\section{III.}

\section{Coastal State JuRusdiction-Subcommittee II}

While the international area beyond coastal state jurisdiction has received more attention than any other area, the heart of the negotiations, in terms of achieving a generally acceptable agreement, is the extent and nature of coastal state jurisdiction in the coastal area. This has been the subject matter with which Subcommittee II has been principally concerned, although it also involves the most controversial aspects of Subcommittee III's work.

Because of procedural questions with respect to the organization of Subcommittee II's work as well as the political importance of the questions involved, this Subcommittee has, on the surface, made less progress than the others in terms of obtaining agreement on single or alternative texts. However, the discussion in the Subcommittee and its working group 
and the corridor negotiations have indicated the broad lines of a compromise between coastal, maritime, and international interests in the coastal area which must clearly form the basic ingredients of a generally acceptable law of the sea package. The key elements are a 12-mile territorial sea accompanied, on the one hand, by international guarantees of transit through and over international straits up to 24 miles in width overlapped by the 12-mile territorial sea, and, on the other hand, by broad coastal state resource management jurisdiction beyond the 12-mile territorial sea that does not result in interference with navigation and other nonresource uses. The most difficult issues in respect of marine pollution and scientific research with which Subcommittee III has dealt also relate to this area of coastal state jurisdiction beyond the 12-mile territorial sea.

\section{Territorial Sea and Straits Used for International Navigation}

It is with respect to nonresource uses of the oceans-principally navigation and overflight-that the greatest concern has been expressed regarding the deterioration of respect for traditional law, and in particular the freedoms of the high seas. The preparatory negotiations reveal very widespread agreement on protection for these uses of the oceans.

There is perhaps broader agreement on the inclusion of a 12-mile maximum limit for the territorial sea in a final treaty than on any other issue. However, it must be emphasized that for many states this is conditioned upon satisfactory resolution of other issues in the treaty, particularly those concerning straits and coastal resources. Among those few proposals that do not contemplate a 12-mile limit, only the articles submitted by Brazil would establish a full territorial sea with control over navigation and overflight out to 200 nautical miles. ${ }^{19}$ The similar proposal of Uruguay in fact limits general control over navigation and overflight to 12 nautical miles, ${ }^{20}$ the 200-mile zone of sovereignty and jurisdiction in the proposal of Ecuador, Panama, and Peru similarly includes a narrower zone of unspecified breadth for navigational controls, ${ }^{21}$ and the 200-mile zone of national ocean space proposed by Malta also distinguishes a 12-mile zone for navigation purposes. ${ }^{22}$ The Chinese proposal does not specify a precise maximum limit for the territorial sea. ${ }^{23}$

The nature of the legal regime for the territorial sea generally has not been a major issue. Very few proposals have dealt with it at all, and

19 Brazil: Draft articles containing basic provisions on the question of the maximum breadth of the territorial sea and other modalities or combinations of legal régimes of coastal State sovereignty, jurisdiction or specialized competences, 28 REP. III, 29 (1973); 12 ILM 1222 (1973).

2w Urugnay: Draft treaty articles on the territorial sea, 28 ReP. III, 23 (1973).

21 Ecuador, Panama and Peru: Draft articles for inclusion in a convention on the law of the sea, Working paper, 28 REP. III, 30 (1973); 12 ILM 1224 (1973).

2. Malta: Preliminary draft articles on the delimitation of coastal State jurisdiction in ocean space and on the rights and obligations of coastal States in the area under their jurisdiction, 28 REP. III, 35 (1973).

23 China: Working paper on sea area within the limits of national jurisdiction, 28 REP. III, 1 (1973); 12 ILM 1230 (1973). 
most states seem content to continue in force the rules contained in the Geneva Convention of 1958 on the Territorial Sea and the Contiguous Zone. ${ }^{24}$

The principal problem arises in connection with international straits overlapped by a 12-mile territorial sea. In the negotiating context, proposals regarding the regime of innocent passage in the territorial sea can be seen in large measure as concerned primarily with the regime in straits overlapped by the territorial sea, and in opposition to proposals for a regime of "free transit" in straits used for international navigation presented early in the negotiations by the United States ${ }^{25}$ and by the USSR. ${ }^{20}$

A simple solution to the straits problem might have been one that excluded straits from any provision permitting the extension of the territorial sea, at least where such extension did not leave a suitable high seas corridor for navigation and overflight. However, it was recognized that this might entail broader restrictions on coastal state rights than was necessary to protect transit, and that a corridor might be difficult to establish in some circumstances. Accordingly, the United States proposed that in straits used for international navigation, vessels and aircraft in transit should enjoy the same freedom of navigation and overflight for the purpose of transit as they have on the high seas, but with coastal state authority to establish suitable corridlors to which such transit would be restricted. ${ }^{27}$ In explaining the unacceptability of innocent passage as a guarantee of transit, the United States has noted three reasons among others:

(I) Innocent passage is defined by the Territorial Sea Convention ${ }^{28}$ as passage that does not prejudice the peace, good order, or security of the coastal state. Some coastal states have interpreted this language as permitting them selectively to control or interfere with passage by ships of other states on the basis, for example, of flag or destination or the character of the vessel or cargo.

(2) Innocent passage under the Convention requires submarines to navigate on the surface.

(3) Innocent passage does not include a right of overflight of the territorial sea.

In response to the concerns of coastal states regarding safety, of navigation and pollution, the United States has also suggested adherence to international standards for pollution control, mandatory application of international traffic separation schemes, and strict liability for accidents caused by failure to adhere to such schemes and similar ICAO air navigation regulations.

24 Supra note 2.

25 USA: Draft articles on the breadth of the territorial sea, straits, and fisheries, 26 REP. 241-45 (1971).

26 USSR: Draft articles on straits used for international navigation, 27 REp. 162-63 (1972).

27 USA: Draft articles on the breadth of the territorial sea, straits, and fisheries, supra note 25 .

${ }^{28}$ Art. 14, supra note 2. 
The Soviet straits article elaborates specific duties of the flag state with respect to transit, an approach which appears to seek a means of accommodating the need to respect certain coastal state interests with the need to avoid coastal state interference.

Those states opposed to free transit, primarily certain straits states but by no means all of them, argue in essence that innocent passage should apply to all parts of the territorial sea, including the territorial sea overlapping straits. Accordingly, their proposals are written in terms that apply to the territorial sea generally. This is the case with the Chinese proposal ${ }^{29}$ and with the proposal of Cyprus, Greece, Indonesia, Malaysia, Morocco, the Philippines, Spain, and Yemen. ${ }^{30}$ Both proposals speak in terms of innocent passage but are more restrictive of navigation than current rules of innocent passage. Fiji has also introduced very elaborate articles on innocent passage which are also, in some respects, more restrictive than the current regime. ${ }^{3 x}$

The proposal of Malta contemplates a system of coastal state regulation based on regulations established by, and subject to review by, an international organization, with compulsory dispute settlement procedures in the event of disagreement. ${ }^{32}$

The Declaration of the Organization of African Unity states:

That the African States in view of the importance of international navigation through straits used as such endorse the regime of innocent passage in principle but recognize the need for further precision of the regime. ${ }^{33}$

The negotiation of specific articles relating to straits, of course, requires some understanding as to their applicability. The Convention on the Territorial Sea and the Contiguous Zone prohibits the suspension of innocent passage in straits used for international navigation between one part of the high seas and another part of the high seas or the territorial sea of another state. The U.S. straits proposal uses the same definition in connection with free transit. ${ }^{34}$ However, this proposal as well as others specify that they do not affect specific agreements applicable to particular straits (e.g., the Montreux Convention in the case of the Turkish Straits); and this exception appears to be widely accepted. Malta's proposal refers

20 China: Working paper on sea area within the limits of national jurisdiction, supra note 23.

sa Cyprus, Greece, Indonesia, Malaysia, Morocco, Philippines, Spain, and Yemen: Draft articles on navigation through the territorial sea including straits used for international navigation, 28 REP. III, 3 (1973).

31 Fiji: Draft articles relating to passage through the territorial sea, 28 REP. III, 91 (1973); 12 ILM 1251 (1973).

32 Malta: Preliminary draft articles on the delimitation of coastal State jurisdiction in ocean space and on the rights and obligations of coastal States in the area under their jurisdiction, supra note 22 .

33 Organization of African Unity: Addis Ababa Declaration, 28 REP. II, 4 (1973); 12 ILM 1200 (1973).

34 USA: Draft articles on the breadth of the territorial sea, straits, and fisheries, supra note 25. 
in relevant part to "straits less than twenty-four miles wide which are, or can be, used for international navigation." ss The proposals of certain straits states contain a qualified prohibition on suspension of innocent passage "through straits used for international navigation which form part of the territorial sea." 36 The Soviet proposal for freedom of transit refers to "straits used for international navigation between one part of the high seas and another part of the high seas." 37 The Italian proposal for free transit follows the Geneva Convention definition, but then excludes from free transit and applies innocent passage to straits which are not more than six miles wide, lie between the coasts of the same state, and are near other routes of communication between the parts of the sea connected by the straits. ${ }^{38}$

There can be little doubt from the preparatory negotiations of the critical importance for a successful conference of adequate guarantees of transit in straits. Most states which have been silent on the issue appear to understand this. No state can be expected to agree to subject its communications with the rest of the world to the discretion of another state, nor is it clear whether any state would in fact gain by, the acquisition of a discretionary right to interfere with transit of straits where the exercise of that right would be a matter of such fundamental concern to so many others.

Proposals regarding archipelagos present potential difficulty for navigation and overflight. Fiji, Indonesia, Mauritius, and the Philippines ${ }^{30}$ have proposed that "archipelagic states" should be able to enclose all waters lying within their outermost islands as "archipelagic waters" in which only innocent passage by ships would be permitted, which could be limited by coastal state regulation and confined to corridors designated by that state. There are basic questions concerning the definition of an archipelago, that is, the precise area than can be enclosed, as well as navigation and overflight rights within the area. Moreover, although island nations would have very considerable resource rights within an archipelago on the basis of coastal state resource jurisdiction under a law of the sea treaty without any special provisions regarding archipelagos, it should be noted that these archipelago proposals do not provide for any, coastal state duties regarding resources within the archipelago and that the effect of these proposals could be to extend resource jurisdiction further seaward of the island group than would otherwise be the case.

35 Malta: Preliminary draft articles on the delimitation of coastal State jurisdiction in ocean space and on the rights and obligations of coastal States in the area under their jurisdiction, supra note 22.

${ }^{86}$ Cyprus, Greece, Indonesia, Malaysia, Morocco, Philippines, Spain, and Yemen: Draft articles on navigation through the territorial sea, including straits used for international navigation, supra note 30 .

87 USSR: Draft article on straits used for international navigation, supra note 26.

88 Italy: Draft article on straits, 28 REP. III, 70 (1973); 12 ILM 1230 (1973).

39 Fiji, Indonesia, Mauritius and the Philippines: Draft articles on archipelagoes, 28 REP. III, 102 (1973); 12 ILM 1263 (1973). 
The United Kingdom archipelago proposal ${ }^{40}$ attempts a solution to the basic problems of definition and of navigation and overflight. Like the proposal of Fiji and others, it limits the application of the principle to island states. The proposal is that no baseline connecting outermost points on the outermost islands may be longer than 48 nautical miles and that the ratio of the area of the sea to the area of land territory within the perimeter must not exceed five to one. The U.K. proposal would apply the same regime, under the Convention, as would govern straits used for international navigation to those parts of archipelagic waters used, before ratification of the Convention, as routes for international navigation between one part of the high seas and another part of the high seas or the territorial sea of another state. In all other parts of archipelagic waters, innocent passage would apply. If it were to satisfy the stipulated criteria, a state could declare itself to be an archipelagic state on ratifying or acceding to the Convention by filing a declaration, chart, and accompanying certification regarding these criteria. This would include a list of routes used for international navigation, which could be modified under specific treaty articles. Compulsory dispute settlement procedures could be invoked as to the application of the articles.

\section{Coastal State Resource Jurisdiction}

The problem of coastal state resource jurisdiction beyond the territorial sea involves more interests of more states than any other problem in the law of the sea negotiations. It is therefore not surprising that more proposals of more different countries deal with this problem, or certain aspects of it, than any other.

However, particularly in this area, numbers can be misleading. Ten ${ }^{41}$ of some 27 different resource proposals deal with the concept of a coastal state exclusive economic zone or analogous approaches, and their application. $\mathrm{Six}^{42}$ deal essentially with the problem of landlocked and other

40 United Kingdom: Draft article on the rights and duties of archipelagic States, 28 REP. III, 99 (1973); 12 ILM 1259 (1973).

11 Conference of the Caribbean Countries on Problems of the Sea: Text of the Santo Domingo Declaration, 27 REP. 70-72 (1972); 66 AJIL 918 (1972); II ILM 892 (1972); African States Regional Seminar on Law of the Sea held in Yaounde: General Report, 27 REP. 73-76 (1972); Kenya: Draft articles on exclusive economic zone concept, 27 REP. 180-82 (1972); Organization of African Unity: Addis Ababa Declaration, supra note 33; Colombia, Mexico and Venezuela: Draft articles of treaty, 28 REP. III, 19 (1973); Iceland: Jurisdiction of coastal States over natural resources of the area adjacent to their territorial sea, 28 REP. III, 23 (1973); China: Working paper on sea area within the limits of national jurisdiction, supra note 23; Argentina: Draft articles, 28 REP. III, 78 (1973); Algeria, Cameroon, Ghana, Ivory Coast, Kenya, Liberia, Madagascar, Mauritius, Senegal, Sierra Leone, Somalia, Sudan, Tunisia, United Republic of Tanzania and Zaire: Draft articles on exclusive economic zone, 28 REP. III, 87 (1973); 12 ILM 1246 (1973); Pakistan: breadth of territorial sea and boundaries of exclusive economic zone, 28 REP. III, 106 (1973).

42 Netherlands: Working paper concerning the concept of an intermediate zone, UN Doc. A/AC.138/86 (March 16, 1973); Afghanistan, Austria, Belgium, Hungary, Nepal, Netherlands, Singapore: Preliminary working paper, supra note 11; Afghanistan, Austria, 
geographically disadvantaged states. Four ${ }^{43}$ deal primarily with delimitation between opposite or adjacent states. Three ${ }^{44}$ concern only seabed resources, while nine ${ }^{45}$ primarily concern fisheries.

By the end of 1971 tentative steps had been taken toward concrete solutions of the problems of coastal state resource jurisdiction. Four specific proposals had been introduced, two by the United States on seabed resources ${ }^{46}$ and fisheries ${ }^{47}$ respectively, one by seven landlocked and shelf-locked states dealing with seabed resources, ${ }^{48}$ and a comprehensive draft treaty by Malta. ${ }^{49}$ In a broad sense, the major types of alternatives were already foreshadowed by these proposals.

As 1972 came to a close, the alternatives were more clearly evident, as was the importance of fisheries to an overall solution. The Declaration of Santo Domingo and the Report of the Yaounde Seminar, ${ }^{\text {,0 }}$ as well as

Belgium, Bolivia, Nepal, and Singapore: Draft articles on resource jurisdiction of coastal States beyond the territorial sea, 28 REP. III, 85 (1973); 12 ILM 1243 (1973); Uganda and Zambia: Draft articles on the proposed economic zone, 28 REP. III, 89 (1973); 12 ILM 1249 (1973); Jamaica: Draft articles on regional facilities for developing geographically disadvantaged coastal States, 28 ReP. III, 110 (1973); Netherlands: Proposal concerning an intermediate zone, 28 REP. III, 111 (1973); 12 ILM 1271 (1973).

43 Turkey: Draft article related to the following items: 2.3.1; 5.3; 6.7.2, 28 REP. III, 22 (1973); see also Tunisia and Turkey: Amendments to the Turkish draft articles, 28 REP. III, 7I (1973); Romania: Working paper on certain specific aspects of the régime of islands in the context of delimitation of the marine space between neighbouring States, 28 REP. III, 106 (1973); Japan: Principles on the delimitation of coastal seabed area, 28 REP. III, III (1973); I2 ILM 1270 (1973).

44 USA: Draft article for a chapter on the rights and duties of States in the coastal sea-bed economic area, 28 REP. III, 75 (1973); 12 ILM 1235 (1973); Afghanistan, Austria, Belgium, Hungary, Nepal, Netherlands, Singapore: Preliminary working paper, supra note 11; USSR: Rough draft of basic provisions on the question of the outer limit of the continental shelf, 28 REP. III, 28 (1973); 12 ILM 1223 (1973).

45 USA: Revised draft fisheries articles, 27 Rep. 175-79 (1972); see also USA: Working paper on special considerations regarding the management of anadromous fishes and highly migratory oceanic fishes, 28 REP. III, 11 (1973); USSR: Draft article on fishing, 27 REp. 158-61 (1972); Bulgaria, Czechoslovakia, Hungary, Poland, and the USSR: Declaration on principles of rational exploitation of the living resources of the seas and oceans, 27 REP. 78-80 (1972); Australia and New Zealand: Principles for a fisheries régime, 27 REP. 183-87 (1972); Japan: Proposal for a régime of fisheries on the high seas, 27 REP. 188-96 (1972); Canada: Working paper on management of the living resources of the sea, 27 Rep. 164-74 (1972); Canada, India, Kenya, Madagascar, Senegal, and Sri Lanka: Draft articles on fisheries, UN Doc. A/AC.138/SC.II/L.38 and Corr. I, (July 16, 1973); Ecuador, Panama, and Peru: Draft articles on fisheries in national and international zones in ocean space, 28 REp. III, 107 (1973); 12 ILM 1267 (1973); Zaire: Draft articles on fishing, 28 Rep. III, 114 (1973).

46 USA: Draft United Nations convention on the international sea-bed area, supra note 4.

47 USA: Draft articles on the breadth of the territorial sea, straits, and fisheries, supra note 25.

18 Afghanistan, Austria, Belgium, Hungary, Nepal, Netherlands, Singapore: Preliminary working paper, supra note 11 .

49 Malta: Draft ocean space treaty, supra note 14.

so Conference of the Caribbean Countries on problems of the sea: Text of the Santo Domingo Declaration, supra note 41; African States Regional Seminar on Law of the Sea held in Yaounde: General Report, supra note 41. 
draft articles by Kenya ${ }^{51}$ set out the concept of an exclusive economic zone or patrimonial sea. The Moscow Declaration, ${ }^{52}$ and fisheries proposals by the USSR ${ }^{53}$ and Japan ${ }^{54}$ emphasized an international approach to fisheries problems. Canada ${ }^{55}$ and the United States ${ }^{56}$ addressed with greater precision the problem of harmonizing coastal state jurisdiction with the objectives of fisheries management, while Australia and New Zealand took a step toward reconciling the alternatives. ${ }^{57}$

In important respects, 1973 was a year for elaboration. Both the Santo Domingo Declaration and the later Declaration of the Organization of African Unity ${ }^{58}$ were refined into treaty texts. ${ }^{59}$ A specific application of the concept of the exclusive economic zone to fisheries was incorporated in a proposal introduced by six states from different regions. ${ }^{.0} \mathrm{~A}$ large number of drafts dealing with specific aspects of the problem were introduced.

One underlying assumption of all these proposals seems to have been that the nonresource uses referred to in the High Seas Convention ${ }^{61}$ will be protected beyond a 12-mile territorial sea. Some of the proposals specifically recognize freedoms of navigation, overflight, and the laying of submarine cable and pipelines, while others use more general formulations.

Another common element has been the establishment of extensive coastal state rights over resources. The issue does not appear to be whether broad coastal state resource jurisdiction can emerge from the Conference for this seems to be understood as a basic condition of general agreement. The critical issue is rather whether there can be agreement on sufficient treaty safeguards for the interests of other states and the international community in general to permit-or in the view of some, to justify-widespread agreement on such broad jurisdiction.

As for the limits of this coastal state economic jurisdiction, the distance of 200 nautical miles has the broadest support, particularly among proponents of an exclusive economic zone. For some, particularly African states, this is a uniform limit proposed for a coastal zone involving jurisdiction over fisheries, seabed minerals, pollution, and scientific research.

61 Kenya: Draft articles on exclusive economic zone concept, supra note 41.

s: Bulgaria, Czechoslovalia, Hungary, Poland, and the USSR: Declaration on principles of rational exploitation of the living resources of the seas and oceans, supra note 45.

53 USSR: Draft article on fishing, supra note 45.

54 Japan: Proposal for a régime of fisheries on the high seas, supra note 45.

ss Canada: Working paper on management of the living resources of the sea, supra note 45.

So USA: Revised draft fisheries articles, supra note 45.

${ }^{57}$ Australia and New Zealand: Principles for a fisheries régime, supra note 45.

58 OAU: Addis Abada Declaration, supra note 33.

s9 Colombia, Mexico, and Venezuela: Draft articles of treaty, supra note 41; Algeria, Cameroon, Ghana, Ivory Coast, Kenya, Liberia, Madagascar, Mauritius, Senegal, Sierra Leone, Somalia, Sudan, Tunisia, United Republic of Tanzania, and Zaire: Draft articles on exclusive economic zone, supra note 41.

Bo Canada, India, Kenya, Madagascar, Senegal, and Sri Lanka: Draft articles on fisheries, supra note 45.

61 Supra note 2. 
For others, including most Latin American states and other states with broad continental margins, jurisdiction over seabed resources (but not fisheries) would extend to the outer edge of the continental margin beyond 200 miles. Since coastal species of fish migrate beyond 200 miles in certain places, a system of coastal state preferential rights beyond the 200-mile zone has been proposed by a number of states, including some African states. ${ }^{62}$ The U.S. fisheries proposal would establish coastal state jurisdiction over coastal species and anadromous species such as salmon throughout their migratory range.

A number of landlocked and shelf-locked states proposed a limit of 200 meters depth or 40 nautical miles for coastal state seabed jurisdiction, with an additional intermediate zone of 40 nautical miles in which the coastal state would have preferential and veto rights over exploitation. The USSR proposed a limit of the 500 meter isobath or 100 miles, whichever is further from shore, for coastal state seabed jurisdiction.

In addition, there appears to be widespread agreement that coastal state jurisdiction over nonliving resources should be exclusive in the sense that the coastal state would have discretion with respect to access to, and the disposition of those resources. The only exceptions have been the proposal of Uganda and Zambia that this jurisdiction would be exercised jointly by coastal and landlocked states in a region or subregion, ${ }^{03}$ and the proposal of the Netherlands for limited rights of access by "geographically disadvantaged States" off the coast of "geographically advantaged States." 64

Finally, there appears to be increasing recognition that coastal state jurisdiction over fisheries will be accompanied by treaty obligations regarding access by other states in specified circumstances.

(1) Seabed Resources: There are only two systems under consideration for seabed exploitation. One is based on coastal state jurisdiction, the other on an international regime and organization for the area beyond coastal state jurisdiction. To the extent that the only interest served in areas under coastal state jurisdiction would be those of the nearest coastal state, an irreconcilable dispute over the limits of that jurisdiction, and accordingly the limit of the international seabed area, necessarily develops. If, on the other hand, other states' concerns with broad coastal state jurisdiction can be accommodated, the location of the outer limit of that jurisdiction becomes a less difficult issue.

One problem with broad coastal state resource jurisdiction is that of protecting freedom of navigation. Fortunately, all proposals contemplate express treaty protection of navigation in areas of resource jurisdiction. However, great care will be needed to prevent expansion of such jurisdiction through unilateral interpretation of what is necessary to protect resource interests in ways that might adversely affect navigation.

62 Canada, India, Kenya, Madagascar, Senegal, and Sri Lanka: Draft articles on fisheries, supra note 45 .

${ }^{63}$ Uganda and Zambia: Draft articles on the proposed economic zone, supra note 42.

os Netherlands: Proposal concerning an intermediate zone, supra note 42. 
Another problem to which exclusive coastal state seabed minerals jurisdiction gives rise concerns protection of the marine environment from pollution from seabed exploration and exploitation activities. Whatever may be said regarding the discretion of a state to pollute its land areas, there is no assurance that pollution from vast seabed areas off the coast will affect only the nearest coastal state. It is in the interests of coastal states themselves to agree to observe certain minimum international environmental standards elaborated with the participation of all, while retaining the right to impose higher standards with respect to seabed resource activities under their jurisdiction.

A third problem relates to the stability of such foreign investment as a coastal state permits in the seabed area subject to its resource jurisdiction. Most of the world's offshore oil reserves are found in the continental margins off the coast, and these constitute a large and increasingly important part of total global reserves. The technological and capital requirements for offshore oil development are considerable and, for most countries, not indigenously available.

It is clear that the potential stability of investment is increasingly affecting both the availability of technology and capital and the relative economic rent in different countries. Investors are increasingly diverting capital to less economic areas of lower political risk. This helps neither the coastal developing country nor the consumer.

In addition, we have already witnessed far too many disputes over the taking of foreign investments. If a principal objective of the Law of the Sea Conference is to prevent conflict over ocean uses, then this is one problem that clearly merits closest attention. It is not merely a problem of guaranteeing property rights; it is one of ensuring a stable system of expectations among producing and consuming nations alike, upon which plans may be based in a time of increasing energy problems.

No one contests the legitimate desire of a coastal state to maximize its economic return from seabed mineral resources. Its right to be a tough negotiator and even to stipulate in advance the terms of any agreement with investors-whether a license, service contract, or joint venture-is also uncontested. But its practical ability to derive maximum benefit from its seabed resource jurisdiction is in fact adversely affected to the extent that the investor fears the bargain will not be kept. The greater this risk, the greater the tendency to avoid the investment or compensate for the risk in terms of rate of return.

Accordingly, the United States has proposed that contracts with foreign investors be respected, that expropriation be subject to just compensation, and that resolution of these problems be subject to compulsory dispute settlement procedures which can be initiated by the coastal state, the state of the nationality of the investor, or if the latter does not act, the investor. ${ }^{.8}$ This accomplishes what the entire treaty should accomplish for the oceans: the establishment of common expectations; the narrowing and depoliticiza-

os USA: Draft articles for a chapter on the rights and duties of States in the coastal sea-bed economic area, supra note 44. 
tion of disputes that do arise; and the resolution of problems through impartial legal processes.

Finally, it is clear that differences of opinion regarding the limits of coastal state economic jurisdiction relate in important respects to the problem of allocation of benefits. The problem is most clearly evident in the case of a landlocked country. If coastal states enjoy all the benefits from areas under their jurisdiction, the broader that jurisdiction, the smaller the international seabed area from which all countries will enjoy benfits. Moreover, there are also coastal states with similar problems. Some are shelf-locked, that is, they have limited possibilities for extending their jurisdiction far offshore because of their geographic situation. This, for example, is the case with states that border on enclosed or semienclosed seas, or in other areas such as the Gulf of Guinea where the coastline is concave. In addition, the resource potential of different offshore areas varies greatly. Since petroleum is most likely to be found in continental margins, the absence of a broad continental margin seriously reduces the potential benefits, whatever the limits of jurisdiction may be.

A number of solutions have been proposed. One is to establish the limits of coastal state jurisdiction so that substantial oil reserves likely to be exploited in the near future are within the international area. This, of course, creates difficulties in view of the desires and expectations of coastal states with respect to economic jurisdiction. The long debates over the continental margin beyond 200 miles indicate that even a 200mile limit of coastal state economic jurisdiction is not completely satisfactory to a significant number of coastal states.

Another approach has been to establish an intermediate zone of mixed coastal and international authority, running from relatively narrow to relatively broad limits. The original U.S. trusteeship proposal was in essence such a solution, ${ }^{86}$ as was the 1971 working paper introduced by certain landlocked and shelf-locked countries. ${ }^{67}$ The problem with these proposals is that, to varying degrees, they entailed limitations on coastal state resource management policy that many coastal states considered undesirable, potentially confusing, or unnecessary to achieve the object of the proposals.

The new U.S. articles on the coastal seabed economic area ${ }^{88}$ seek to resolve these problems by clearly establishing coastal state exclusive resource management jurisdiction, subject to treaty obligations protecting other uses of the area and including an obligation to share revenues from a part of the area. In his Oceans Policy Statement of May 23, 1970, President Nixon indicated that the revenues should be used for international community purposes, particularly for the benefit of developing

${ }_{68}^{6}$ USA: Draft United Nations convention on the international sea-bed area, supra note 4.

${ }^{67}$ Afghanistan, Austria, Belgium, Hungary, Nepal, Netherlands, Singapore: Preliminary working paper, supra note 11 .

68 USA: Draft articles for a chapter on the rights and duties of States in coastal sea-bed economic area, supra note 44. 
countries. The new articles submitted by certain landlocked and shelflocked states take a similar approach but provide for differences in the rate of contribution by developed and developing coastal states. Canada, the United Kingdom, and others have also endorsed revenue-sharing systems as a means of solving the problem of the outer limit of coastal state seabed resource jurisdiction. In view of the very sharp dispute that erupted last summer among the economic zone supporters over whether the outer limit should be 200 miles alone, or 200 miles or the edge of the continental margin, a number of countries will doubtless be considering revenue sharing as a means of bridging this gap.

Another approach would involve benefit-sharing arrangements among states in the same region. The problems, of course, are that most developed states are not in the same region as most developing countries, that the distribution of resources off different continents is by no means equal, and that certain coastal developing countries that could qualify for a significant share of international benefits on the basis of need under an international system would in essence only be donors under a regional system. Nonetheless, the states of Africa, which has the largest number of landlocked countries, and perhaps the smallest resource potential off most of its coast of all the continents, have indicated strong inclinations toward an exclusively regional solution to the allocation problem within the 200-mile limit of an exclusive economic zone.

(2) Fisheries: Without in any way underestimating the importance of seabed mineral resources, the complexity of the fisheries problem is probably without parallel in the law of the sea negotiations. There appear to be few if any states that would be unaffected by alterations in the international rules affecting the supply of protein from the sea. Fish will disregard jurisdictional lines in the ocean drawn by man, fisherman will follow the fish, and those trying to regulate the fishermen and protect the fish will inevitably be faced with a problem transcending purely national solutions.

Despite the silence of some proposals on some of the issues, there appears to be wide agreement that any fisheries regime should promote the following objectives:

(i) Conservation. Overfishing can seriously reduce the availability of fish for future years, with adverse impact both on protein supply and on those who derive their livelihood from the fishing.

(ii) Maximum utilization. Underutilization of renewable resources is wasteful and clearly undersirable in view of the global need for inexpensive sources of animal protein.

(iii) Equitable allocation. It appears to be widely recognized that the coastal state should, in principle, have first call on access to fish stocks off its coast to the extent of its capacity to fish. Coastal fishing fleets cannot, and normally do not, fish far from their home base, and thus have no economic alternative to fishing close to home. The problems of accommodating the preference of two or more coastal states to the same stock, of allocating the remainder, and of dealing with the situation in which the current fishing capacity of all coastal and other vessels with respect to a 
stock exceeds what can be caught, consistently with adequate conservation measures, are among the most difficult and controversial issues. Most proposals provide at least for access under stated conditions for other states in the region, including landlocked and other geographically disadvantaged states.

(iv) Economic efficiency. There is growing concern that excess fishing capacity, at least in some areas, is causing smaller economic returns, raising the price of fish, and complicating efforts to ensure conservation and equitable allocation of fish stocks. However, this is largely a problem of the type of management measures adopted rather than of the jurisdiction to manage, and is therefore largely outside the scope of the Law of the Sea Conference.

It is also generally recognized that any law of the sea treaty will necessarily have to be accompanied by continuing international fisheries arrangements of a bilateral, regional, or special global character. Every comprehensive proposal dealing with fisheries refers to these arrangements either in mandatory or permissive terms.

The fisheries proposals submitted deal with three types of questions among others: jurisdiction to manage fisheries and coordination of fisheries management; conservation and other duties of the manager; and allocation. All are to some extent interrelated.

Proposals for a 200-mile economic zone entail coastal state management jurisdiction within the zone. A number include provisions for management by international or regional organizations beyond the zone.

The draft articles on fisheries submitted by Canada, India, Kenya, Madagascar, Senegal, and Sri Lanka ${ }^{69}$ include an exclusive fishery: zone coterminous with the exclusive economic zone and are in essence an elaboration of the concept. These articles include additional management provisions on specific fisheries problems:

(i) They recognize the coastal state's special interest in the maintenance of the productivity of living resources in the area adjacent to the zone and give it preferential rights to those resources based on harvesting capacity, and authority to take measures pursuant thereto.

(ii) The states of a region may regulate living resources beyond the zone when the resources are of limited migratory habits and breed, feed, and survive on the resources of the region.

(iii) In respect of fisheries of highly migratory habits outside the limits of the zone, regulations would be made by the authority designated for that purpose.

(iv) A blank article is included on "anadromous species," such as salmon, which breed in rivers but migrate far out to sea.

The Australia-New Zealand paper ${ }^{70}$ states that the basic concept would be to establish coastal state responsibilities and control over the coastal

6r Canada, India, Kenya, Madagascar, Senegal, and Sri Lanka: Draft articles on fisheries, supra note 45.

70 Australia and New Zealand: Principles for a fisheries régime, supra note 45. 
species, described as nonsedentary, free swimming species that inhabit nutrient bearing areas adjacent to the coast.

The U.S. draft articles ${ }^{71}$ do not include a specific limit, but provide for coastal state jurisdiction over coastal species to the full extent of their migratory range offshore, jurisdiction by the coastal state of origin over anadromous species such as salmon throughout their migratory range beyond the territorial sea, and management of highly migratory species such as tuna by international or regional organizations. They also provide for agreement among coastal states with respect to coastal and anadromous species that migrate through waters adjacent to more than one coastal state, and for notice and consultation with other states concerned.

The Soviet draft article ${ }^{72}$ preserves the regulatory functions of existing international fisheries organizations for the future but provides that, in areas where they do not exist, the coastal state may establish measures itself in areas directly adjacent to a 12-mile limit, in agreement with states also engaged in fishing in the areas. However, this does not include jurisdiction over allocation except that preferential rights based on harvesting capacity would be accorded to the coastal state of origin with respect to anadromous species and to developing coastal states with respect to other species in areas directly adjacent to a 12-mile limit.

The Japanese draft articles ${ }^{73}$ provide for coastal state special interests and preferential rights in adjacent waters, to be implemented by agreement with other states concerned. Highly migratory and anadromous species would be exempt from such special interests and rights. The draft articles of Uganda and Zambia ${ }^{74}$ provide for administration of fisheries jurisdiction in the exclusive economic zone by all states in a region or subregion.

These proposals indicate that the practical approaches to problems of jurisdiction over fisheries management are not nearly as far apart as their philosophical premises. All of them appear to be amenable to elaboration in a manner that adequately takes into account the migratory characteristics of different species of fish. If this is done, the major issue would be the extent to which a coastal state must share or coordinate its management responsibilities with other states in the region and with states fishing in the area. Since it is obvious that this will have to be done in any coastal region where stocks of fish migrate off the coast of more than one state, the problem narrows to one of management participation by landlocked and other geographically disadvantaged states and by distant-water fishing states.

The proposed duties of the coastal state as fisheries manager relate primarily to the global interest in maintaining and increasing the short and long-term supply of protein from the sea at minimum possible cost: by conservation measures assuring that fishing does not exceed levels which ensure maximum stock levels of future generations of a stock, and by maximum

71 USA: Revised draft fisheries articles, supra note 45.

i USSR: Draft article on fishing, supra note 45.

73 Japan: Proposals for a régime of fisheries on the high seas, supra note 45.

7s Uganda and Zambia: Draft articles on the proposed economic zone, supra note 42. 
utilization assuring that restrictions on fishing do not produce lesser yields than can be taken within sound conservation limits.

While the United States has stressed these coastal state obligations, many proposals regarding an exclusive economic zone are silent in this respect. However, Canada has endorsed them, and the Australia-New Zealand articles contain them. The proponents of articles that omit such duties argue that obligations of this character are not necessary, as it is in the interests of the coastal state to ensure conservation, and that the coastal state has every reason to permit maximum utilization, if it can collect some economic rent, presumably in the form of license fees. Others argue that the record of states with respect to land and marine animals within their jurisdiction indicates that this premise is open to serious doubt. Species have been disastrously handled in some instances, and even regulated access by foreign fishermen to internal waters and the territorial sea is the exception rather than the rule despite the fact that not all species in those areas are fully exploited by coastal state fishermen.

All proposals contemplate that the coastal state can at least reserve to its own vessels that portion of a stock of coastal species that its vessels can harvest and that this preference would increase with harvesting capacity, although the Soviet articles provide for the continuation of existing regional arrangements and exclude developed coastal states. The Japanese articles restrict the preference to a "major portion" of the stock and contain special limitations on the preferential rights of developed coastal states.

In the absence of special provisions, a 200 -mile exclusive economic zone would presumably include an exclusive or preferential right with respect to anadromous and highly migratory species in the zone as well as coastal species. The U.S. and Soviet proposals apply a preferential right to anadromous species throughout their migratory range, which is frequently well beyond 200 miles; the Japanese proposal excludes anadromous species. The U.S. and Japanese proposals exclude highly migratory species from coastal state jurisdiction. The effect of the articles introduced by Canada and others in respect to highly migratory and anadromous species is unclear, although Canada has endorsed control of anadromous species by the coastal state of origin.

Assuming agreement on a duty to ensure maximum utilization of stocks, the issue is who may fish for portions of stocks subject to a coastal state preference that are not for the time being fully utilized by the coastal state. The options appear to include coastal state discretion at one extreme and nondiscrimination at the other. The effect of a number of proposals is to give priority to neighboring states, particularly landlocked and other geographically disadvantaged states, to states that have traditionally fished in the area, or to both groups in one or another order.

The traditional fishing issue is an important but very narrow one; it arises only when the sum total of the coastal state's harvesting capacity and traditional fishing levels exceed $100 \%$ of the allowable catch. In essence, it is a problem of transition. Extreme solutions would involve either permitting the coastal state preference to expand without reference 
to traditional fishing or, on the other hand, preventing any expansion of the preference when the combined total of coastal state harvesting capacity and traditional fishing levels reaches $100 \%$. Intermediate solutions might include gradual phase-out or systems of compensation. The problem is a major one primarily in the Northern hemisphere. It should be noted that general acceptance of a solution to this and perhaps other problems could be facilitated if it were made clear that traditional fishing provisions apply only to fishing that occurred before entry into force of the treaty, and that no new or increased traditional fishing rights can accrue by virtue of new or increased foreign fishing that may be permitted after the treaty enters into force.

Virtually nothing has been said in the Seabed Committee about allocation with respect to highly migratory species. Their migratory habits not only render effective regulation and conservation virtually impossible without international agreement but seriously complicate any attempt to apply a geographic system of coastal state preferences. Indeed, attempts to do so could render a significant part of every state's tuna fleet useless for most of the season. However, international tuna commissions have given special treatment to developing coastal states, and these precedents provide every reason to think that coastal state interests could be accommodated by a system of international management that ensures coastal state participation and equitable allocation.

IV.

Polidtion and Scientific Research-Subcommitte III

The mandate of Subcommittee III was functional rather than territorial: it was to deal with the problems of pollution and scientific research everywhere in the oceans. The preparations to date, however, have made clear that the critical problems lie in the area of coastal state jurisdiction beyond the territorial sea, and this largely coincides, as far as jurisdictional issues are concerned, with the work of Subcommittee II. Most exclusive economic zone proposals have provided for coastal state jurisdiction over pollution and scientific research within the economic zone.

\section{Pollution}

Questions relating to the prevention of marine pollution were largely disregarded during the early phases of the preparatory work of the Seabed Committee with no proposals formally submitted until the spring of 1973. Consequently the preparatory work is incomplete, and several major issues, such as the jurisdiction to take enforcement measures against vessels, were not considered in any depth or detail. However, the number of major pollution control issues being considered is fairly small, and the proposals tabled generally cover a broad spectrum of alternatives on those major issues.

The Working Group on Marine Pollution was established late in the summer 1972 session of the Seabed Committee and began substantive 
meetings in March 1973. Only six proposals ${ }^{75}$ were presented in March and only four of these (Australia, Canada, Malta, and the USSR) were comprehensive. Two texts were agreed, on the general and particular obligations of states to prevent pollution and to protect the marine environment. $^{76}$ The summer session produced seven more proposals, ${ }^{77}$ of which five were comprehensive (U.S., France, Kenya, Norway, and a four-power draft from Ecuador, El Salvador, Peru, and Uruguay) and two dealt only with enforcement (Netherlands and Japan). During the summer session, texts were prepared, either agreed or in the alternative, on global and regional cooperation, monitoring, technical assistance, international standards, and national standards. ${ }^{78}$ There was some discussion of texts on enforcement but no agreement on draft articles. Questions of liability and responsibility, exemption of military vessels and aircraft, and compulsory dispute settlement were not discussed.

The language of all of the proposals on the general and particular obligations of states to prevent pollution and to protect the marine environment is quite vague, as were the agreed drafts produced at the spring session. ${ }^{79}$ However, during the negotiations in the spring session many developing countries strongly supported the inclusion of language such as "using for this purpose the best practicable means in accordance with their capabilities" to ensure that the obligations were qualified and not absolute.

\footnotetext{
75 Australia: Working paper on preservation of the marine environment, UN Doc. A/AC.138/SC.III/L.27 (March 6, 1973); Canada: Draft articles for a comprehensive marine pollution convention, UN Doc. A/AC.138/SC.III/L.28 (March 9, 1973); USSR: Draft articles for a convention on general principles for the preservation of the marine environment, UN Doc. A/AC.138/SC.II/L.32 (March 15, 1973); Malta: Draft articles for the preservation of the marine environment (including, inter alia, the prevention of pollution), UN Doc. A/AC.138/SC.III/L.33 (March 16, 1973); Netherlands: Observations concerning the preservation of the marine environment including the prevention of marine pollution, UN Doc. A/AC.138/SC.III/L.35 (March 23, 1973); USA: Working paper on competence to establish standards for the control of vessel source pollution, UN Doc. A/AC.138/SC.III/L.36 (April 2, 1973).

${ }^{76}$ Report of Subcommittee III, Committee on the Peaceful Uses of the Sea-bed and the Ocean Floor Beyond the Limits of National Jurisdiction (hereinafter cited as REp. of SC.III) 28 REP. I, 86-88 (1973).

77 USA: Draft articles on the protection of the marine environment and the prevention of marine pollution, UN Doc. A/AC.138/SC.IH/L.40 (July 13, 1973); Kenya: Draft articles on prevention and control of pollution in the marine environment, UN Doc. A/AC.138/SC.III/L.41 (July 16, 1973); Norway: Draft articles on the protection of the marine environment against pollution, UN Doc. A/AC.138/SC.III/L.43 (July 19, 1973); France: Draft articles concerning the rights exercisable by coastal States for the purpose of preventing marine pollution, UN Doc. A/AC.138/SC.III/L.46 (July 20, 1973); Ecuador, El Salvador, Peru, and Uruguay: Working paper on the preservation of the marine environment, UN Doc. A/AC.138/SC.III/L.47 and Corr. I (July 24 and 26, 1973); Netherlands: Draft articles on the enforcement of international provisions for the prevention of marine pollution from vessels, UN Doc. A/AC.138/SC.III/ L.48 (Aug. 10, 1973); Japan: Proposal on enforcement measures by coastal States for the purpose of preventing marine pollution, UN Doc. A/AC.138/SC.III/L.49 (Aug. 13, 1973).

78 REP. of SC.III, supra note 76, at 91-102.

$79 I d$., at $86-88$.
} 
During the summer, this approach culminated in proposals to require that economic factors, including the stage of development of individual countries, be taken into account in both the formulation and implementation of all marine pollution control standards. After lengthy discussion and opposition to these proposals by many developed states, including the U.S. and Canada, alternative texts were formulated on the question of global and regional cooperation to establish standards, one of which included a general reference to economic factors and the other of which did not. ${ }^{80}$

Texts were also agreed during the summer on technical assistance and monitoring. ${ }^{81}$ The technical assistance text requires states to promote programs of scientific, technical, educational, and other assistance to developing countries for pollution control, to provide assistance for minimizing the effects of major pollution incidents, and to develop contingency plans to deal with such incidents. The monitoring text requires states to "employ suitable systems of observation, measurement, evaluation and analysis to determine the risk or effect of pollution on the marine environment" and "to disseminate ... data and information obtained . . . to states likely to be affected and to the international organizations concerned."

The discussion of the source of pollution control standards and the jurisdiction to prescribe standards consumed over two weeks of meetings during the summer session. Although there was some narrowing of alternatives and consolidation of positions, the Working Group was only able to produce a lengthy series of alternative texts, two on land-based pollution, six on seabed-based pollution, six on vessel-source pollution, and three specifically on the competence of individual states to establish and adopt standards.

The two alternatives on land-based pollution standards are a text requiring states to adopt national standards and to endeavor to establish international standards and a separate ten-word text simply requiring states to take appropriate measures. ${ }^{82}$

On seabed-source pollution, ${ }^{83}$ the basic issue was whether or not there should be a minimum floor of internationally established standards that each state would be required to apply to economic activities in the seabed area under its jurisdiction. Most states did support a minimum floor of standards for seabed economic activities, with the coastal state having the right to apply its own higher standards; but a group of countries opposed minimum international standards as being inconsistent with the exclusive economic zone concept. While a number of states wanted the new Seabed Authority to prescribe the international standards, others were quite reluctant to agree to that concept, at least before the structure of the $\mathrm{Au}$ thority is fully negotiated.

On the question of the source of international standards for vesselpollution control, ${ }^{84}$ two of the six alternative texts proposed the establish-

so Id, at 91 .

sa Id., at 93 .

s4 Id, at 95-98. s1 Id., at 92-93.

83 Id., at 94-95. 
ment of international standards by the Intergovernmental Maritime Consultative Organization, while one specified the Seabed Authority, and another the United Nations Environment Program. One supported international standards generally, while another stated that no standards higher than those of the flag state should be applied to vessels.

The most controversial item in the discussion of pollution standards was whether the coastal state would have the right to set higher standards for vessels transiting a large zone off its coast. The issue is clearly presented in the three altemative texts on the competence of individual states to establish standards. ${ }^{85}$

One approach would require all vessels to comply with the internationally agreed standards, and would allow higher standards to be applied by flag states to their own vessels and by port states to vessels entering their ports but would not allow higher coastal state standards in other respects. The states supporting this approach argued that standards should generally be uniform to enable compliance and that both navigational and environmental interests should be taken into account when standards are formulated, which would be more likely in international negotiations than if coastal states fix the standards. They pointed out that special standards for special areas or regions could be formulated through the international process.

Another approach would allow a coastal state to apply special standards in a zone beyond its territorial sea whenever, in its view, adequate international standards have not been established; some of the states supporting this concept would support port state and Hag state rights in addition, while some would oppose port state rights. The basic arguments for this approach are that the drawing-up of international standards will be a slow process and that flag and port states will not adequately protect coastal states' environmental interests.

A third approach, while permitting coastal state standards in a broad area, would require that such standards not be incompatible with standards adopted by developing states for their Hag vessels.

The issue of a coastal state's rights to prescribe and enforce rules in a zone raises a very serious threat of interference with navigation in such a zone. Those who oppose a pollution control zone basically argue that such coastal state rights are unnecessary and that such rights are completely different in kind from the economic rights, need for which is the basic impetus for a zone of coastal jurisdiction. In this connection, it was noted that shipping to and from a majority of coastal states, while en route, would have to pass within 200 miles of at least one other state, and would accordingly be subject to interference if coastal states were given jurisdiction to establish pollution standards for vessels transiting the area.

Questions of enforcement were briefly discussed but the Working Group could not agree on the presentation of alternative texts. The U.S. proposal ${ }^{86}$ relies on flag state enforcement against its vessels, port state en-

$85 \mathrm{Id}$., at $98-100$.

86 USA: Draft articles on the protection of the marine environment and the prevention of marine pollution, supra note 77 . 
forcement against vessels entering its ports regardless of where the violation took place (the Netherlands proposal also includes this right), ${ }^{87}$ and two types of extraordinary coastal state action-enforcement in emergency. situations threatening major harmful damage to the coast and enforcement against all vessels of a certain flag as authorized by the dispute settlement tribunal after finding that the flag state has persistently and unreasonably failed to take enforcement measures against its vessels.

Other proposals, including those of Australia, ${ }^{88} \mathrm{Canada}_{,}^{80} \mathrm{Kenya}^{80}$ and the four-power draft, ${ }^{91}$ depend basically on coastal state enforcement in a zone beyond the territorial sea. (Canada and Kenya also specifically include flag state enforcement duties). France ${ }^{92}$ and Japan ${ }^{93}$ proposed limited coastal state enforcement in a zone beyond the territorial sea. Japan proposed rights of investigation and prosecution for violation of international standards regarding dumping and discharge. The French proposal would allow coastal state investigation in a zone for violation of certain conventions but would permit prosecution in only two special circumstances of violations of the Ocean Dumping Convention. ${ }^{94}$

The problem of preventing pollution from ships relates in important respects to the problem of protecting navigation. It arises, for example, in connection with the territorial sea, particularly straits, in connection with proposals regarding archipelagos, and in connection with proposals for coastal state pollution controls over ships beyond the territorial sea, either in an "economic zone" or in some other manner. An adequate accommodation of navigational concerns with proposals for coastal state jurisdiction over pollution is not easily achieved. It becomes difficult to distinguish between pollution control jurisdiction over navigation and the sort of jurisdiction exercised in a territorial sea. A large number of states could be very adversely affected by the exercise of broad jurisdiction over pollution.

The issue of state responsibility and liability was not discussed but several proposals have been tabled. Canada ${ }^{95}$ and Kenya ${ }^{9 B}$ provide for

87 Netherlands: Draft articles on the enforcement of international provisions for the prevention of marine pollution from vessels, supra note 77 .

ss Australia: Working paper on preservation of the marine environment, supra note 75.

80 Canada: Draft articles for a comprehensive marine pollution convention, supra note 75.

90 Kenya: Draft articles on prevention and control of pollution in the marine environment, supra note 77.

91 Ecuador, El Salvador, Peru, and Uruguay: Working paper on the preservation of the marine environment, supra note 77.

9: France: Draft articles concerning the rights exercisable by coastal States for the purpose of preventing marine pollution, supra note 77 .

${ }_{93}$ Japan: Proposal on enforcement measures by coastal States for the purpose of preventing marine pollution, supra note 77 .

9.4 Convention on the Prevention of Marine Pollution by Dumping of Wastes and other Matter. Adopted Nov. 13, 1972, not yet in force. 6 Dept. State BulL. 711 (1972); 67 AJIL 626 (1973); 11 ILM 1294 (1972).

95 Canada: Draft articles for a comprehensive marine pollution convention, supra note 75.

96 Kenya: Draft articles on prevention and control of pollution in the marine environment, supra note 77 . 
state liability for damage to areas under the jurisdiction of another state, require local remedies in each state, and call for the development of international law on compensation; the U.S. proposal also includes the last two items. ${ }^{97}$ Australia ${ }^{98}$ provides for state liability but does not elaborate further. The United States, ${ }^{90}$ Norwegian, ${ }^{100}$ and four-power ${ }^{101}$ articles provide for general state responsibility, with the United States imposing additional requirements as noted above.

On the question of vessels entitled to sovereign immunity, which was not discussed, four proposals, by Canada, ${ }^{102}$ the United States, ${ }^{103}$ Australia, ${ }^{104}$ and France ${ }^{105}$ follow the precedents in other pollution treaties and state that the provisions shall not apply to such vessels.

Finally, four proposals, those of Malta, ${ }^{108}$ the United States, ${ }^{107}$ Canada, ${ }^{108}$ France, ${ }^{109}$ and Australia, ${ }^{110}$ all would require compulsory settlement of all pollution disputes, either by arbitration or through a tribunal.

\section{Scientific Research}

Six comprehensive working papers and articles on scientific research were introduced in Subcommittee III. ${ }^{111}$ Two additional proposals were

97 USA: Draft articles on the protection of the marine environment and the prevention of marine pollution, supra note 77 .

98 Australia: Working paper on preservation of the marine environment, supra note 75 .

99 USA: Draft articles on the protection of the marine environment and the prevention of marine pollution, supra note 77 .

100 Norway: Draft articles on the protection of the marine environment against pollution, supra note 77.

101 Ecuador, El Salvador, Peru, and Uruguay: Working paper on the preservation of the marine environment, supra note 77.

102 Canada: Draft articles for a comprehensive marine pollution convention, supra note 75 .

103 USA: Draft articles on the protection of the marine environment and the prevention of marine pollution, supra note 77 .

${ }^{104}$ Australia: Working paper on preservation of the marine environment, stupra note 75.

105 France: Draft articles concerning the rights exercisable by coastal States for the purpose of preventing marine pollution, supra note 77 .

106 Malta: Draft articles for the preservation of the marine environment (including inter alia, the prevention of pollution), supra note 75 .

107 USA: Draft articles on the protection of the marine environment and the prevention of marine pollution, supra note 77 .

108 Canada: Draft articles for a comprehensive marine pollution convention, supra note 75.

${ }^{109}$ France: Draft articles concerning the rights exercisable by coastal States for the purpose of preventing marine pollution, supra note 77 .

${ }_{110}$ Australia: Working paper on preservation of the marine environment, stura note 75.

111 Canada: Working paper on principles on marine scientific research, 27 REP. 203 05 (1972); Bulgaria, Poland, Ukrainian Soviet Socialist Republic, USSR: Draft articles for a convention on scientific research in the world ocean, UN Doc. A/AC.138/SC.III/ L.31 (March 15, 1973); Malta: Draft articles on scientific research, UN Doc. A/ AC.138/SC.III/L.34 (March 23, 1973); China: Working paper on marine scientific research, UN Doc. A/AC.138/SC.III/L.42 (July 19, 1973); USA: Draft articles for a chapter on marine scientific research, UN Doc. A/AC.138/SC.III/L.44 (July 19, 
presented on the specific question of coastal state consent for scientific research in areas under its jurisdiction. The Working Group on Scientific Research and Transfer of Technology was the last to begin work, and could not consider all these draft articles or review the two texts prepared during informal consultations. ${ }^{112}$

The most critical law of the sea issue with respect to scientific research is whether or not coastal state consent will be required to carry on scientific research in areas of coastal state resource jurisdiction.

Those arguing against a consent requirement emphasized the benefits of research to the entire international community, noting that these related to an understanding not only of the oceans but of the total global environment. Research in one locality could have an important bearing on a problem of much more general scope. It was pointed out that, since resource exploration and exploitation would be subject to coastal state jurisdiction, the coastal state need not fear the effect of scientific research data, but to the contrary could have much to gain from new information. Experience with consent requirements under the Continental Shelf Convention ${ }^{113}$ was cited in support of the view that these requirements constitute an impediment to research and have unnecessarily caused increased costs, delay, and cancellation of research projects.

It would appear from a variety of the proposals presented that a coastal state's basic concerns, from a resource management point of view, are the bona fides of the research project, participation in the research project, availability of all data and samples, and, particularly in the case of developing coastal states, the technical means to assess the implications of the research for its economic interests. Complex computer data and unanalyzed samples may not be very meaningful to a country with limited indigenous research capabilities.

The two approaches most frequently discussed both appear to suffer from a failure to accommodate the relevant interests involved in scientific research within the area of coastal state economic jurisdiction. Freedom of scientific research, as proposed by certain Eastern European countries, places exclusive emphasis on the benefits of scientific research. A requirement of coastal state consent, as proposed by Canada, ${ }^{114} \mathrm{China}^{115}$ and Brazil, Ecuador, El Salvador, Peru, and Uruguay ${ }^{116}$ gives similar priority to coastal state interests.

Some see a compromise solution in terms of placing certain obligations on the coastal state in connection with a requirement that consent be

1973); Brazil, Ecuador, El Salvador, Panama, Peru, and Uruguay: Working paper on scientific research within the zone subject to the sovereignty and jurisdiction of the coastal State, UN Doc. A/AC.138/SC.III/L.45 (July 19, 1973).

${ }^{112}$ REP. of SC.III, part. III. B, Report of Working Group 3, supra note 76, at 102.

113 Art. 5(8), supra note 2.

${ }_{114}$ Canada: Working paper on principles on marine scientific research, supra note 111.

115 China: Working paper on marine scientific research, supra note 111.

118 Brazil, Ecuador, EI Salvador, Panama, Peru, and Uruguay: Working paper on scientific research within the zone subject to the sovereignty and jurisdiction of the coastal State, supra note 111. 
sought for the conduct of scientific research. Thus, for example, Italy proposed to deal with the not infrequent situations in which no response is received from the coastal state for a long time, if at all, by presuming consent in the absence of a reply within a certain period of time. Others, such as the United States, see the compromise in terms of specifying certain obligations regarding coastal state interests that would obviate the need for consent and thereby avoid the dangers of unnecessary restrictions on scientific research.

Consistent with its general approach to oceans problems, Malta proposed resolving the problem through international regulation of scientific research beyond a 12-mile limit. ${ }^{117}$

It would appear that a first step in solving the problem of scientific research in the area of coastal state economic jurisdiction might be to prepare a list of those specific obligations of the scientific researcher which are necessary to protect coastal state interests in both seabeds resources and fisheries. The list in the U.S. proposal ${ }^{118}$ contains the following elements:

(i) advance notification to the coastal state, including a description of the project;

(ii) certification regarding bona fides of the project;

(iii) arrangements for coastal state participation;

(iv) sharing of all data and samples with the coastal state;

(v) open publication of results;

(vi) assistance to the coastal state in assessing the implications of the research results for its economic interests; and

(vii) compliance with all applicable international environmental standards.

If such a list could be internationally agreed upon, the standards for harmonizing the international and coastal interests would be established. Compulsory dispute settlement procedures would then assure both the coastal state and the scientist of adherence to those standards, of means to resolve differences that might arise, and of a gradual development of authoritative interpretation based on impartial respect for all the interests involved.

V.

\section{ConcLusion}

Those who discount the probability of chaos in the oceans if the Law of the Sea Conference does not succeed generally seem to maintain that there is existing law and proceed to explain their view of what the law is. The Conference was called, not because there is no law, but because states do not agree on many significant aspects of that law. The negotiations reveal that they also do not agree (although to a significantly lesser degree) on what the law should be in the future. What precisely is left

117 Malta: Draft articles on scientific research, supra note 111.

118 USA: Draft articles for a chapter on marine scientific research, supra note 111. 
of "international" law if states proceed increasingly to interpret it as best suits their interests? "Custom and practice" is a convenient doctrine to invoke in theory, and certainly has an important role. But how consistent with our view of the world in which we want to live is a system that requires acquiescence or resistance, against a clear historical background of serious conflict over some of the issues?

In this situation, if a treaty is to be truly meaningful, it must not only deal reasonably with all of the specific issues but, more importantly, it must justify acquiescence in its terms on the basis of the broader purposes of establishing an equitable system of order for the oceans.

To achieve this, the United States has stated in the clearest possible terms that two elements are essential. First, the treaty must be widely accepted by all segments of the international community. Second, means for the peaceful and compulsory settlement of disputes arising under the treaty must be ensured.

Reference has been made to the critical role of compulsory dispute settlement in connection with specific issues. Some more general elaboration is relevant here.

The developing factual (as distinguished from legal) situation in the oceans is one in which every country increasingly believes that it has, in effect, the option of pronouncing and attempting to achieve relevant acquiescence in its interpretation of the law, provided it is prepared to run such risks as may be entailed. Such a system can operate through existing customary law, or, in effect, through unilateral interpretation of treaties. The degree to which this can be done in the case of a treaty is largely a function of the specificity of the treaty and the legal talent applied to the endeavor. Given the current trends in the law of the sea, there is reason to believe the process might continue even if a treaty were widely ratified. In the broadest sense, the purpose of the law of the sea negotiations is to put an end to the direct relationship that such a system entails between the enjoyment of a right and the application of power. A system of compulsory, impartial, third-party, adjudication is thus an essential element of the overall structure.

For this reason, the United States has now complemented what amounts to a comprehensive set of proposals on basic substantive issues involved in the negotiations with new draft articles ${ }^{219}$ providing for the resolution by a new Law of the Sea Tribunal of disputes not settled by other means. It may be hoped that the very existence of such procedures would enable lawyers in their respective governments to keep even initial interpretations within a fairly limited range. While the articles permit a variety of agreed means for settling disputes, the choice of a new specialized tribunal rather than the International Court of Justice was based on considerations of expertise, on the special "administrative law" functions the tribunal may have in connection with the deep seabeds, and on the greater flexibility in al-

119 USA: Draft articles for a chapter on the settlement of disputes, UN Doc. A/ AC.138/97 (Aug. 21, 1973); 12 ILM 1220 (1973). 
lowing private parties to appear before such a tribunal in specific instances, such as essentially "contractual" disputes under the international regime for the deep seabeds. Of course, reference of a question of international law to the International Court by the Tribunal is not precluded.

There is some reason to believe that the traditional difficulties in negotiating compulsory dispute settlement may be attenuated by the general recognition that international interests of one type or another exist in virtually all parts of the ocean and that those interests will be specifically dealt with in the treaty. It might be noted, for example, that the fisheries proposal of the USSR refers to arbitration.

This is all a very large order. And the time available is running short, as unilateral actions and the pressure for such actions increase. Indeed provisional application of certain aspects of a treaty before full entry into force would appear to be necessary to take care of certain urgent problems, particularly regarding the deep seabed and fisheries. If agreement is not reached in the time schedule elaborated by the UN General Assembly, it is problematic whether agreement can ever be achieved for a long time to come, and then only after much unnecessary conflict and waste. Among the riches and promises of the oceans, there is also great danger of chaos and conflict; it is to be hoped that the danger is clearly perceived before the community of nations discards its chance to defend itself with a just and universally respected system of law. 